TARNOWSKIE STUDIA TEOLOGICZNE 35 (2016) NR 2, S. 91-107 http://dx.doi.org/10.15633/tst.2107

Barbara Marcinkowska ${ }^{1}$

UNIWERSYTET PAPIESKI JANA PAWŁA II W KRAKOWIE

\title{
Analogie i genealogie modlitwy w trzech religiach monoteistycznych
}

Cechą człowieka religijnego jest zaangażowanie jego wszystkich władz, zatem: umysłu, woli, uczucia, także zmysłów, w przeżywanie osobowego kontaktu z Bogiem. Postawa podporządkowania się Bogu i zaufania do Niego przejawia się w kulcie religijnym ${ }^{2}$. Podstawowym aktem kultu obecnym w każdej religii jest modlitwa. Temat modlitwy jest przedmiotem licznych publikacji i badań naukowych, które, biorąc pod uwagę różnorodne ujęcia tej kwestii, próbują wyjaśnić jej istotę. Wobec bogactwa form, sposobów i okoliczności towarzyszących modlitwie nie jest możliwe podanie jej krótkiej, jednoznacznej definicji.

Modlitwa jako podstawowy akt kultu towarzyszy człowiekowi niemal od zawsze. Podlegała różnym wpływom, w zależności od biegu historii, a także uwarunkowań społecznych i kulturowych oraz cywilizacyjnych, $\mathrm{w}$ jakich się rozwijała. $\mathrm{W}$ niniejszym artykule zostanie przybliżona istota modlitwy w chrześcijaństwie, a także w judaizmie i islamie, ukazane zostaną również ich wzajemne powiązania.

\section{Czym jest modlitwa?}

Modlitwa jest obecna w każdym systemie religijnym. Człowiek zwraca się do bóstwa, aby nawiązać z nim kontakt, otrzymać pomoc, oddać mu cześć bądź wypełnić rytualny obowiązek ${ }^{3}$. W religiach monoteistycznych modlić

1 Barbara Marcinkowska - w 2014 roku ukończyła studia licencjackie na Uniwersytecie Papieskim Jana Pawła II w Krakowie Wydział Teologiczny Sekcja w Tarnowie. Doktorantka teologii w zakresie teologii biblijnej na UPJPII wT w Tarnowie.

2 Zob. K. Bukowski, Religie świata wobec chrześcijaństwa, Kraków 1997, s. 27.

3 Na początku modlitwę utożsamiano z magicznymi zaklęciami; wierzono, iż wyrażenie życzeń słowami prowadzi do ich realizacji. Z czasem modlitwa przekształciła się w wezwanie 
się znaczy „stanąć w obliczu Boga w czci i miłości”". Modlitwa jest jedną z najważniejszych i najpotrzebniejszych czynności w życiu człowieka. Jest także aktem wynikającym z jego wolności. Według Karla Rahnera modlić się to znaczy „otworzyć serce Bogu”'

Modlitwa chrześcijańska „jest wzniesieniem duszy do Boga”6. Jako akt rozumnego i wolnego człowieka, stworzonego na obraz Boga, jest wyrazem współpracy człowieka ze swoim Stwórcą, Zbawicielem i Uświęcicielem. Jej celem jest nawiązanie osobistego kontaktu z Bogiem. Jest to możliwe dzięki miłości przenikniętej wiarą. Człowiek zwraca się do Boga z prośbą, uwielbieniem, pragnieniem dobra, w zamian otrzymuje miłosierdzie i łaskę. Podstawą dobrej modlitwy jest gotowość oddania się Bogu, pełnienia Jego woli ${ }^{7}$ i poświęcenia czasu dla Niego. Michel Quoist poucza, że nie należy modlić się w pośpiechu, lecz „umieć zatrzymać się przed Panem, by $\mathrm{Mu}$ obszerniej mówić o naszym życiu, tak jak dziecko, które wyszło na chwilę, a po powrocie długo opowiada swemu ojcu, co robiło" ${ }^{\text {. }}$.

\section{Modlitwa w judaizmie i islamie}

Największe religie monoteistyczne to: judaizm, chrześcijaństwo i islam. Mają one pewne elementy wspólne związane z modlitwą ${ }^{9}$.

\section{Modlitwa w judaizmie}

Modlitwy Żydów - narodu, który wywarł ogromny wpływ na duchową historię ludzkości, były przeniknięte treściami objawionymi przez Boga.

do personalnie pojmowanych istot nadprzyrodzonych. W wyniku dalszego rozwoju ukształtowała się stała struktura modlitwy złożona $\mathrm{z}$ wezwania do bóstwa, przypomnienia o wzajemnych zobowiązaniach oraz prośby. Celem modlitwy początkowo było pozyskanie wymiernych dóbr doczesnych. Później stała się środkiem zjednoczenia z bóstwem oraz osiągnięcia zbawienia. Zob. Mały słownik religioznawczy, red. Z. Poniatowski, Warszawa 1969, s. 286-287.

K. Rahner, Kiedy się modlisz..., Paryż 1968, s. 9.

K. Rahner, Kiedy się modlisz..., s. 9-11.

6 S. Matea, Modlitwa prośby, „Ateneum Kapłańskie” 55 (1963) t. 66 z. 5, s. 338.

7 Zob. S. Matea, Modlitwa prośby, s. 338-339.

8 M. Quoist, Modlitwa i czyn, Warszawa 2002, s. 8.

9 Zob. J. Gnilka, Koran i chrześcijanie, Kielce 2010, s. 9. 
Izraelici „przyjęli ideę jedynego Boga, sformułowali jednoznaczny kodeks moralny, uznali życie ludzkie za święte, ustanowili Szabat, dzień siódmy jako dzień odpoczynku”" ${ }^{\text {. }}$ Na gruncie ich religii powstały dwie największe religie monoteistyczne: chrześcijaństwo i islam ${ }^{11}$.

Dopóki w Jerozolimie była świątynia, głównym aktem kultu było składanie ofiar ze zwierząt ${ }^{12}$. Po zburzeniu budowli nadrzędnym aktem rytualnym stała się modlitwa ${ }^{13}$. Według zasad liturgii uporządkowanych przez przywódcę żydowskiego Gamaliela funkcjonują trzy codzienne modlitwy, odmawiane rano, po południu i wieczorem ${ }^{14}$. Najważniejszą i najbardziej uroczystą spośród codziennych modlitw jest modlitwa poranna. Nie wolno przed jej rozpoczęciem spożywać posiłku ani podejmować żadnej pracy $^{15}$.

W szabat i święta odprawia się uroczyste obrzędy, a w Sądny Dzień (Jom Kippur) odmawia się także modlitwę na zakończenie dnia zwaną Ne’ila (dosłownie: zamykanie bram). Każdy obrzęd zawiera dwie główne modlitwy. Pierwsza z nich to Szema, zawierająca trzy fragmenty Biblii. Druga zaś to Amida, inaczej Szemone Esre. Zawiera ona błagania, prośby i podziękowania ${ }^{16}$. Podczas Amidy obowiązuje postawa stojąca, ze złączonymi stopami, rękami wzniesionymi nad głową i twarzą zwróconą w kierunku Jerozolimy. Szema natomiast może być recytowana w każdej pozycji ${ }^{17}$. Chociaż przybranie właściwej postawy modlitewnej jest dla Żydów sprawą ważną, to najistotniejszym elementem każdej modlitwy jest koncentracja ${ }^{18}$.

${ }^{10}$ N. Kameraz-Kos, Święta i obyczaje żydowskie, Warszawa 2006, s. 7.

${ }_{11}$ Zob. N. Kameraz-Kos, Święta i obyczaje żydowskie, Warszawa 20o6, s. 7-8; Enzyklopädie der Religionen, Hrsg. M. Elser, S. Ewald, G. Murrer, Augsburg 1990, s. 142.

${ }^{12}$ Jako podstawowy akt kultu ofiara sama w sobie była modlitwą. Jednak zazwyczaj towarzyszyła jej modlitwa słowna. Zob. R.de Vaux, Instytucje starego Testamentu, t. 2, Poznań 2004, s. 469.

${ }^{13}$ Obrzędy modlitewne organizowano w tych samych porach, w których wcześniej składano ofiary. Zob. M. Bloom, Żydowski mistycyzm a magia, Kraków 2011, s. 68.

${ }^{14}$ Zasługą Gamaliela jest zapoczątkowanie organizacji kultu i sformalizowanie tefillah, czyli modlitwy Osiemnastu Błogosławieństw. Zob. M. Bloom, Żydowski mistycyzm a magia, s. 176.

${ }_{15}$ Zob. W. Tyloch, Judaizm, Warszawa 1987, s. 311.

${ }_{16}$ Zob. N. Solomon, Judaizm, Warszawa 1997, s. 8o-81.

${ }_{17}$ Zob. R. de Vaux, Instytucje Starego Testamentu, t. 2, s. 470-471.

18 Zob. N. Solomon, Judaizm, s. 82. 
Do modlitwy zakłada się specjalną szatę modlitewną nazywaną tallit ${ }^{19}$ lub cicit $^{20}$. Ważnym elementem stroju modlitewnego są także filakterie ${ }^{21}$. Mężczyźni powinni mieć podczas modlitwy nakrytą głowę $e^{22}$. Poza odpowiednim strojem w religii żydowskiej funkcjonują inne znaki przynależności religijnej. Jednym z nich jest umieszczona przy drzwiach wejściowych mezuza mająca przypominać o obecności Boga ${ }^{23}$.

W judaizmie istnieje zarówno modlitwa prywatna, jak i wspólnotowa. Ich przykłady są utrwalone na kartach Bibliii ${ }^{24}$. Pierwotne modlitewniki żydowskie nie zawierały modlitw indywidualnych, bowiem każdy mógł wypowiadać taką modlitwę według własnego uznania. Czasem była to tylko myśl lub westchnienie ${ }^{25}$. Modlitwy wspólnotowe odmawiano w synagodze albo w Bet ha-midrasz (dom nauki). Warunkiem rozpoczęcia tej modlitwy było osiągnięcie kworum uczestników, tj. co najmniej dziesięciu mężczyzn w wieku 13 lat i powyżej ${ }^{26}$.

Miejscem spotkania z Bogiem była dla Żydów Świątynia w Jerozolimie. Gdy podczas niewoli babilońskiej zostali oni pozbawieni dostępu do niej, zaczęli zbierać się w szabat każdego tygodnia we własnych domach, aby wspólnie czytać Torę i pisma proroków ${ }^{27}$.

Nie ulega wątpliwości, że modlitwa jest integralną częścią życia codziennego Izraelitów. Praktykujący Żydzi pamiętają o obecności Boga przez cały

${ }^{19}$ Jest to prostokątna, zazwyczaj biała tkanina $\mathrm{z}$ frędzlami, wykonana $\mathrm{z}$ wełny, bawełny lub jedwabiu. Zob. Judaizm, red. M. Dziwisz, Kraków 1989, s. 236.

${ }^{20}$ Szata mająca przypominać noszącemu o powinności poświęcenia całego życia służbie Bogu. Zob. W. Tyloch, Judaizm, s. 310.

${ }_{21} \mathrm{Z}$ hebr. tefilin - niewielkie skórzane pudełeczka w kształcie sześcianu zawierające teksty biblijne spisane na pergaminie. Zob. N. Solomon, Judaizm, s. 310.

${ }^{22}$ Zob. K. Banek, Islam, w: Słownik wiedzy o religiach, red. K. Banek, Bielsko-Biała 2007, s. 206.

${ }^{23}$ Pergamin zawierający tekst dwóch pierwszych paragrafów Szema umieszczony w specjalnym futerale, przybijany do drzwi wejściowych domu bądź mieszkania. Zob. S. P. de Vries, Obrzędy i symbole Żydów, Kraków 1999, s. 75-77.

${ }^{24}$ Jedną z najbardziej znanych modlitw indywidualnych jest modlitwa Salomona podczas poświęcenia Świątyni z $1 \mathrm{Krl} \mathrm{8,} \mathrm{22-53.} \mathrm{Ponadto} \mathrm{rabini} \mathrm{podawali} \mathrm{modlitwę} \mathrm{Anny} \mathrm{proszącej}$ o dziecko (1 Sm 1) za wzór szczerej, spontanicznej modlitwy. Zob. N. Solomon, Judaizm, s. 75-77.

${ }_{25}$ Zob. S. P. de Vries, Obrzędy i symbole Żydów, s. 28.

${ }^{26}$ Kobiety początkowo nie uczestniczyły w publicznych obrzędach. Ich rola ograniczała się do modlitwy prywatnej. Zob. N. Solomon, Judaizm, s. 78-79.

${ }^{27}$ Spotkania te $\mathrm{z}$ czasem stały się powszechną praktyką, określaną greckim terminem synagoge. Zob. W. Tyloch, Judaizm, s. 93. 
czas, począwszy od pierwszych chwil po przebudzeniu. Rozpoczynają dzień od modlitwy dziękczynnej, poprzedzającej wykonywanie jakichkolwiek czynności porannych. Chociaż modlitwa ma być wyrazem wewnętrznego przekonania, istnieje w judaizmie szereg zasad określających porę, sposób i okoliczności jej odmawiania. Żydzi wierzą, że modlitwa jest dialogiem, podczas którego Bóg słucha człowieka i odpowiada na jego słowa. Formuły poszczególnych modlitw zawiera modlitewnik, którego część stanowią teksty zaczerpnięte ze Starego Testamentu, głównie z Psałterza i Pięcioksięgu. Modlitewnik nie zawiera modlitwy indywidualnej, którą każdy odmawia według własnego uznania, lecz modlitwy wspólnotowe napisane w języku hebrajskim ${ }^{28}$.

\section{Modlitwa $w$ islamie}

Islam jest najmłodszą religią monoteistyczną ${ }^{29}$. Jego twórcą jest Muhammad Ibn Abd Allah ${ }^{30}$, znany w Europie pod imieniem Mahometa. Świętą księgą

${ }^{28}$ Pomimo że nie każdy Żyd posługiwał się językiem hebrajskim, właśnie w tym języku sprawowano wspólną liturgię. Powodem była troska o zachowanie jedności narodu, także przebywającego w diasporze. Zob. S. P. De Vries, Obrzędy i symbole Żydów, s. 26-27. Dopuszczano jednak także modlitwę w języku ojczystym. Zob. N. Solomon, Judaizm, s. 81.

${ }^{29}$ Islam - druga po chrześcijaństwie pod względem liczby wyznawców religia monoteistyczna, uznawana za religię objawioną. Zob. Mały słownik kultury świata arabskiego, red. J. Bielawski, Warszawa 1971, s. 238.

${ }^{30}$ Muhammad Ibn Abd Allah wywodził się z mekkańskiego plemienia Kurajszytów, z rodu Haszymitów, który stanowił część mekkańskiej arystokracji. Osierocony bardzo wcześnie pozostawał pod opieką stryja oraz mamki beduińskiej. Przez jakiś czas pasał wielbłądy, a jako dorosły człowiek podróżował w karawanach kupieckich w Mekce. W wieku 23 lat rozpoczął służbę u bogatej wdowy Chadidży jako przewodnik karawany. Wkrótce czterdziestoletnia Chadidża została jego żoną i pomimo znacznej różnicy wieku małżeństwo to było trwałe i szczęśliwe. Podczas wędrówek z karawanami Muhammad wielokrotnie spotykał się z przedstawicielami gmin żydowskich i chrześcijańskich, co niewątpliwie wywarło wpływ na jego poglądy religijne. Jak podaje tradycja, pierwszego objawienia doznał podczas snu, kiedy ukazał mu się archanioł Gabriel. Przekonany o swojej misji prorockiej zaczął wzywać do skruchy, dobroci dla biednych, zapowiadał nadejście sądu ostatecznego, oskarżał zamożnych ludzi o zbytnie przywiązanie do dóbr doczesnych i brak miłości bliźniego. Ze względu na głoszone przez niego poglądy nowa religia cieszyła się uznaniem ludzi biednych, natomiast arystokracja odnosiła się do niej z coraz większą wrogością. Pomimo trudności Muhammad powoli stawał się przywódcą politycznym plemion arabskich. Gdy umierał, prawie cała Arabia była zjednoczona w imię głoszonej przez niego religii, skoncentrowanej wokół postaci jedynego Boga i życia przyszłego. Zob. J. Bielawski, Islam, Warszawa 1980, s. 25-43. 
islamu jest $\operatorname{Koran}^{31}$, natomiast jego uzupełnieniem i rozwinięciem - sunna ${ }^{32}$. Kult w islamie zazwyczaj jest pozbawiony oprawy zewnętrznej. Nie ma wizerunków religijnych ani muzyki ${ }^{33}$. Wiara muzułmanów opiera się na pięciu głównych obowiązkach religijnych, nazywanych pięcioma filarami islamu. Są to: wyznanie wiary, modlitwa, jałmużna, post i pielgrzymka do Mekki ${ }^{34}$.

Spośród pięciu wymienionych filarów najbardziej charakterystycznym przejawem pobożności muzułmanów jest modlitwa obowiązkowa, czyli kanoniczna. Modlitwę tę wierni odmawiają pięć razy dziennie ${ }^{35}$. Dokładny czas rozpoczęcia poszczególnych modlitw ogłasza muezzin ${ }^{36} \mathrm{z}$ minaretu,

${ }^{31}$ Koran zawiera to, co Allah objawił prorokowi Muhammadowi za pośrednictwem archanioła Gabriela w latach 610-632. Początkowo był przekazywany ustnie, natomiast po śmierci Muhammada w 632 roku został spisany w 114 rozdziałach - surach. Poza podstawowymi przepisami dotyczącymi prawa, kultu, moralności, życia społecznego i gospodarczego zawiera opowiadania zaczerpnięte $z$ legend arabskich oraz Biblii (wizje sądu ostatecznego, piekła i raju). Zob. J. Danecki, Koran, w: Leksykon religioznawczy, red. W. Tyloch i in., Warszawa 1988, s. $123-124$.

${ }^{2}$ Tradycja złożona z hadisów, czyli opowieści o czynach, gestach i słowach proroka Muhammada. Zob. M. M. Dziekan, Jak modlą się muzułmanie, Warszawa 1997, s. 7.

33 Zob. K. Banek, Islam, s. 158.

${ }^{34}$ Wyznanie wiary - šahāda (arab. zaświadczenie, oświadczenie, świadectwo) - to formuła zawierająca podstawowy dogmat islamu, jakim jest wiara w jednego Boga i w posłannictwo Mahometa: „Nie ma bóstwa oprócz Boga (Allaha), a Mahomet jest wysłannikiem Boga”. Słowa šahādy wypowiada uroczyście każdy, kto przechodzi na islam; szepcze się ją także do ucha nowo narodzonego dziecka. Jako znak przynależności do islamu šahāda jest zatem czymś w rodzaju odpowiednika chrześcijańskiego chrztu. Zob. J. Danecki, Podstawowe wiadomości o islamie, t. 1, Warszawa 1997, s. 130. Drugim filarem wiary jest modlitwa odmawiana obowiązkowo pięć razy dziennie. Jałmużna początkowo polegała na dobrowolnym opodatkowaniu się. Z czasem stała się obowiązkową daniną pobieraną przez wyznaczonych do tego celu urzędników. Jej przeznaczeniem było wspieranie ubogich, budowa meczetów oraz wydatki państwowe. Czwarty filar islamu - post - polega na powstrzymaniu się od wszystkich pokarmów i napojów od świtu do zachodu słońca w miesiącu ramadan. Ostatnim filarem islamu jest obowiązkowa pielgrzymka do Mekki, którą każdy muzułmanin czy muzułmanka mają odbyć co najmniej raz w życiu. Zob. E. Szymański, Islam pierwotny, w: Zarys dziejów religii, red. J. Keller, Warszawa 1986, s. 762-763.

${ }_{35}$ Według tradycji muzułmańskiej Mahomet ustalił pięciokrotne odmawianie modlitwy w ciągu dnia w wyniku rozmowy z Bogiem na początku swej misji. Faktycznie jednak istnieje prawdopodobieństwo, że w wyniku zatargów z Żydami, którzy nie chcieli uznać Mahometa jako własnego proroka, zwiększył on liczbę modlitw z trzech do pięciu, aby różnić się od Żydów. Zob. J. Danecki, Podstawowe wiadomości o islamie, t. 1, s. 132.

${ }^{36}$ Muezzin - niższy urzędnik kultu w meczecie, którego zadaniem jest zwoływanie muzułmanów na modlitwę. Zob. Encyklopedia popularna $P$ WN, red. B. Kaczorowski, Warszawa 2004, s. 566 . 
a w przypadku braku minaretu, $\mathrm{z}$ innego podwyższonego miejsca ${ }^{37}$. Modlitwę można odprawiać w dowolnym miejscu, zatem w meczecie, w domu czy na wolnym powietrzu. Ważne, aby było to miejsce rytualnie czyste ${ }^{38}$. Czystość rytualna obowiązuje także tych, którzy odprawiają modły. Każdy muzułmanin zobowiązany jest do ablucji, czyli oczyszczenia przed modlitwą. Wszelkie zabrudzenie podczas modlitwy czyni ją nieważną ${ }^{39}$.

Modlący powinien zwracać się twarzą w kierunku Mekki. Jeśli nie wiadomo, w jakim kierunku ona się znajduje, ma modlić się we wszystkich czterech kierunkach świata, a jeśli nie ma na to czasu, wybiera jeden $\mathrm{z}$ nich. Po dokonaniu ablucji należy wypowiedzieć intencję modlitwy - nijja, po czym następuje modlitwa właściwa. Jej treść stanowią różne fragmenty Koranu. Czynności wykonywane podczas modlitwy to skomplikowany układ ruchów określany terminem raka. W przypadku modlitwy zbiorowej odprawianej w piątki, wierni ustawiają się w równych rzędach i naśladują postawę modlitewną prowadzącego. Pierwsze rzędy zajmują mężczyźni, natomiast ostatnie kobiety ${ }^{40}$.

Oprócz modlitwy kanonicznej istnieje $\mathrm{w}$ islamie wiele modlitw nadobowiązkowych, nadal praktykowanych ze względu na tradycję i pobożny zwy$\mathrm{czaj}^{41}$. Ponadto istnieją modlitwy spontaniczne: osobiste prośby skierowane do Boga, modlitwy przebłagalne, prośby o ochronę ${ }^{42}$.

Nurt religijny jest także obecny w twórczości poetyckiej. Islam uznaje szereg postaci ze Starego i Nowego Testamentu za proroków (Adam, Noe, prorocy Starego Testamentu, św. Jan Chrzciciel, Jezus), dlatego funkcjonują

37 Zob. M. M. Dziekan, Jak modla się muzułmanie, s. 13.

${ }^{38}$ Niedozwolone jest odmawianie modlitwy w takich miejscach, jak: cmentarze, rzeźnie, łaźnie, śmietniska, które są uznawane za nieczyste. Zob. A. Borowski, Islam. Zagadnienia wybrane, Katowice 2009, s. 38-39.

${ }^{39}$ Zob. J. Bielawski, Islam, s. 106-107.

${ }^{40}$ Przyczyną takiego rozmieszczenia nie jest niższa pozycja społeczna kobiety, lecz ustrzeżenie mężczyzn przed rozproszeniem myśli podczas modlitwy. Zob. M. M. Dziekan, Jak modla się muzutmanie, s. 13-17.

${ }^{41}$ Należą do nich modlitwy towarzyszące zawieraniu umów, pielgrzymkom, modlitwy w obliczu niebezpieczeństw, podczas składania ofiar, czuwania w miesiącu ramadan, a także wiele modlitw za zmarłych. Zob. Z. Pawłowicz, Modlitwa i mistyka islamu a chrześcijaństwo, „Ateneum Kapłańskie” 79 (1987) t. 108 z. 3, s. 408.

${ }^{42}$ Modlitwę taką odmawia się na przykład w drodze do meczetu, podczas wsiadania do pojazdu itd. Modlitwę spontaniczną odmawia się w postawie stojącej, z rękami wzniesionymi ku niebu. Zob. F. Yaken, Co oznacza moja przynależność do islamu, Białystok 200o, s. 17-19. 
również ich modlitwy, zapisane w Koranie. Szczególne znaczenie przypisuje się przekazanym przez tradycję modlitwom proroka Muhammada. One są dla muzułmanina wzorem osobistej rozmowy z Bogiem ${ }^{43}$.

Modlitwa, stanowiąca jeden z pięciu filarów islamu, odgrywa równie ważną rolę w tej religii, jak w judaizmie. Chociaż nie można muzułmanom zarzucić braku gorliwości, wydaje się, że o wiele więcej uwagi przywiązują do zewnętrznej oprawy towarzyszącej modlitwie: czystości rytualnej, układu ruchów, pory poszczególnych modlitw itp.

Bezwzględnym obowiązkiem każdego muzułmanina jest pamięciowe opanowanie arabskich tekstów modlitwy i krótkich sur ${ }^{44}$. Nie wyklucza to jednak możliwości odmawiania dodatkowych modlitw spontanicznych poza recytowanymi tekstami z Koranu.

\section{Specyfika chrześcijańskiej modlitwy względem judaizmu i islamu}

\section{Judaizm a chrześcijaństwo}

Nie ulega wątpliwości, że chrześcijaństwo ma swoje korzenie w religii żydowskiej. Wszak Jezus pochodził z narodu Izraela, a Jego uczniami byli wyłącznie Żydzi. Ewangeliści wielokrotnie podkreślają, że misja Jezusa była skierowana do Żydów ${ }^{45}$. Właśnie im zawdzięcza się rozróżnienie pomiędzy dniem powszednim a świątecznym poprzez wprowadzenie szabatu ${ }^{46}$. Chrześcijaństwo przyjęło to rozróżnienie. Wyznawcy Chrystusa świętują dzień Jego zmartwychwstania, niedzielę.

Zachowanie soboty - szabatu - dnia odpoczynku, czytanie Tory i pism proroków oraz praktyka obrzezania, na którą położono szczególny nacisk, stały się elementami wyróżniającymi Żydów i utwierdzającymi

${ }^{43}$ Zob. M. M. Dziekan, Jak modla się muzułmanie, s. 125.

${ }^{44}$ Zob. A. Borowski, Islam. Zagadnienia wybrane, s. 39.

${ }^{45}$ Spośród licznych uzdrowień, jakich dokonywał Jezus, większość dotyczyła Żydów. On sam także często podkreślał pierwszeństwo Żydów przed poganami (Mt 15, 24; Mt 10, 5), co nie jest w żadnym wypadku oznaką Jego uprzedzenia do innych narodów, lecz koniecznością, która wynikała z ekonomii zbawienia. Chrześcijaństwo miało zatem swój początek w religii Izraela, o czym pisał także święty Paweł w swoich listach ( $\mathrm{Rz} 1,16 ; \mathrm{Rz} 2,10-11)$. Zob. D. Flusser, Chrześcijaństwo religia żydowska, Warszawa 2003, s. 64-69.

${ }^{46}$ Zob. H. von Glasenapp, Judaizm, w: Judaizm, red. M. Dziwisz, Kraków 1989, s. 31. 
ich w przekonaniu, że są narodem wybranym przez Boga spośród innych ludów ${ }^{47}$.

Praktyki religijne pierwszych gmin chrześcijańskich miały wiele wspólnego z obrzędami judaizmu ${ }^{48}$. W Nowym Testamencie są obecne teksty lub odniesienia do starotestamentowych modlitw: $\mathrm{Dz}$ 4, 24 nawiązują do $\mathrm{Wj} 20,11$, Ne 9, 6, a szczególnie do Psalmów (np. Ps 146, 6) ${ }^{49}$. Jedna z najbardziej popularnych modlitw żałobników żydowskich, kadisz, jest podobna do pierwszej części Ojcze nasz z Mt 6, 9-10 ${ }^{50}$. Nowością, jaka pojawiła się w modlitwie chrześcijańskiej, stało się pośrednictwo Jezusa. Zaczęto się modlić do Niego i w Jego imię.

Modlitwa chrześcijanina prowadzi go do Eucharystii. W tym świętym obrzędzie, w klimacie modlitewnym dokonuje się sakramentalne uobecnienie misterium paschalnego Chrystusa ${ }^{51}$. Poza ukierunkowaniem modlitwy chrześcijańskiej na Chrystusa i Jego zbawcze dzieło, jej istotnym elementem jest świadomość obecności Ducha Świętego, który uzdalnia człowieka do wzniesienia myśli do Ojca przez Chrystusa ${ }^{52}$.

Modlitwa Jezusa jest niewątpliwie najdoskonalszym wzorem modlitwy chrześcijańskiej. On, jako potomek narodu żydowskiego, posługiwał się

47 W odróżnieniu od chrześcijaństwa i islamu, które wykroczywszy poza ramy jednego narodu stały się religiami uniwersalistycznymi, judaizm do dziś pozostał religią narodową, ograniczoną do jednego narodu żydowskiego, rozproszonego po całym świecie. Zob. W. Tyloch, Judaizm, s. 93-94; 339.

${ }^{48}$ Ich członkowie nadal przestrzegali prawa żydowskiego, świętowali szabat oraz brali czynny udział w kulcie świątynnym i synagogalnym. Sposób sprawowania Eucharystii i chrztu najważniejszych praktyk religijnych wczesnego chrześcijaństwa - ma wiele wspólnego z modlitwami i gestami, jakie towarzyszyły wieczerzy paschalnej i obchodom szabatu. Zob. M. Miklicz, Chrześcijaństwo (I tysiąclecie), w: Słownik wiedzy o religiach, red. K. Banek, Bielsko-Biała 2007, s. $43-49$.

49 Zob. W. Tyloch, Bogowie czterech stron świata, Łódź 1988, s. 152.

${ }^{50}$ Mt 6, 9-10: „Ojcze nasz, który jesteś w niebie, niech się święci Twoje imię! Niech przyjdzie Twoje królestwo; niech Twoja wola się spełnia na ziemi, tak jak w niebie”. Kadisz: „Przed jego (Domu Izraela) Ojcem, który jest w niebie [...] niech wyniesione i uświęcone będzie wielkie Imię Jego [...] i niech ustanowi panowanie królestwa swego [...] Niech cały Izrael, jako i my, otrzyma obfity pokój z nieba i życie [...], który czyni pokój na wysokościach swoich, niech uczyni pokój nam i całemu Izraelowi” (M. Tomal, Jak modlą się Żydzi. Antologia modlitw, Warszawa 2000, s. 40-41).

${ }^{51}$ Zob. W. Tyloch, Bogowie czterech stron świata, s. 152.

${ }_{52}$ Zob. B. Seremet, Dzieje Apostolskie i listy katolickie, Tarnów 2001, s. 33-35. 
często modlitwami starożytnego Izraela ${ }^{53}$, jednak Jego modlitwa otrzymała zupełnie nowe znaczenie. Siła modlitwy Jezusowej tkwi w mocy Boskiego imienia. W Starym Testamencie było to imię Jahwe, natomiast w Nowym Testamencie - imię Jezusa ${ }^{54}$. Jezus zachowywał gesty, jakimi zazwyczaj posługiwali się Żydzi podczas modlitwy, ale zewnętrzna strona modlitwy była dla Niego sprawą drugorzędnąa ${ }^{55}$. Jezus, ucząc modlitwy Ojcze nasz, nazwał Boga $A b b a^{56}$. Pozwolił uczniom i zachęcił ich, aby oni w ten sposób zwracali się do Boga. Chciał uświadomić Izraelitom, że Bóg jest nie tylko sędzią i władcą, lecz także przyjacielem człowieka. Do Niego należy się zwracać $\mathrm{z}$ dziecięcą ufnością, nadzieją i całkowitym oddaniem ${ }^{57}$.

Wśród przykładów modlitwy chrześcijańskiej na uwagę zasługuje modlitwa św. Szczepana. Jest ona inspirowana modlitwą Jezusa na krzyżu. Szczepan prosi Chrystusa o przebaczenie winy dla tych, którzy go kamienowali: „Panie, nie poczytaj im tego grzechu!” $(\mathrm{Dz} 7,60)^{58}$.

${ }^{53}$ Jednym ze zwyczajów żydowskich była modlitwa błogosławieństwa, którą Jezus odmawiał wielokrotnie: podczas rozmnożenia chleba, kiedy przyszły do Niego dzieci, czy w czasie ostatniej wieczerzy Zob. I. de la Potterie, Modlitwa Jezusa, Mesjasza - Stugi Bożego - Syna Bożego, Kraków 1996, s. 11-28. Modlił się także psalmami zarówno podczas życia w Nazarecie, jak i drogi krzyżowej. Por. Łk 23, 46 - Ps 31, 6; Mk 15,3 4 - Ps 22, 2). Zob. G. Martin, Uczmy się modlić jak Chrystus, Kraków 2003, s. 75. Modlitwa Jezusa przybierała różne formy: błogosławieństwa, uwielbienia, dziękczynienia, a także błagania i prośby, zwłaszcza w imieniu całego Kościoła. Jednak ze względu na to, iż Jezus nie miał grzechu, nie spotkamy u Niego modlitwy winy i prośby o przebaczenie. Zob. R. Cantalamessa, B. Maggioni, Modlić się w Duchu i prawdzie. Modlitwa według Biblii, Kraków 2011, s. 42. Pierwsze miejsce w życiu Chrystusa zajmowała modlitwa pochwalna - uwielbienie Boga, które przenikało całą Jego działalność. Zob. J. Woroniecki, Petnia modlitwy, Poznań 1982, s. 166.

${ }_{54}$ Zob. A. Jasiewicz, Historia kształtowania się modlitwy Jezusowej, „Seminare. Poszukiwania Naukowo-Pastoralne" 25 (2008), s. 405-406.

55 Zob. I. de la Potterie, Modlitwa Jezusa, Mesjasza - Stugi Bożego - Syna Bożego, s. 30-32.

${ }^{56}$ „Abba - było to familiarne zawołanie dzieci żydowskich, jakim zwracały się do swych rodzonych ojców, wyrażając w nim całe swoje zaufanie, miłość, oddanie i pewność, iż doznają od swych ojców najczulszej opieki, [...] poczucie całkowitego bezpieczeństwa i niczym niezmąconej radości” (J. Banak, Modlitwa w Piśmie Świętym, „Materiały Problemowe” 4 [1981], s. $77-78)$.

${ }^{57}$ Nazywanie Boga swoim własnym Ojcem było nie do pomyślenia w środowisku pobożnych Żydów, albowiem tradycja żydowska uważała zbyt poufałe zwracanie się do Boga za bluźnierstwo. Zob. G. Martin, Uczmy się modlić jak Chrystus, s. 12-15; 26-28.

${ }^{58}$ Nowością w stosunku do starotestamentalnych modlitw jest fakt, iż Szczepan, zwracając się do Jezusa, używa terminu zarezerwowanego dotąd tylko dla Jahwe. Zob. F. Jóźwiak, Zna- 
Kontynuatorem takiej modlitwy był św. Paweł ${ }^{59}$. Poza jego własnymi listami poznajemy go głównie z dzieł świętego Łukasza. On w Dziejach Apostolskich ukazuje Apostoła Narodów jako „pełnego pokoju, radości i mocy orędownika Dobrej Nowiny"60. Paweł, będąc Żydem, wypełniał przepisy i zwyczaje żydowskie ${ }^{6}$. Chodził do synagogi i brał czynny udział w sprawowanej tam liturgii. Do Boga zwracał się tak, jak to czyniono w Starym Testamencie, ale swoje modlitwy zanosił do Ojca przez Jego wcielonego Syna, Jezusa. Poprzez zjednoczenie Ojca z Synem modlitwa odmawiana w imię Jezusa sprawia, że i modlący jednoczy się z Ojcem ${ }^{62}$.

Podsumowując kwestię zależności między judaizmem a chrześcijaństwem, trzeba mieć świadomość, że tradycja żydowska, stanowiąca jedno ze źródeł modlitwy chrześcijańskiej, była wzbogacona przez wpływy kultury helleńskiej. Istotne elementy modlitwy chrześcijańskiej, jak ukierunkowanie jej na osobę Chrystusa, jedynego pośrednika między Bogiem i ludźmi oraz obecność w niej Ducha Świętego, nie wykluczają dorobku judaizmu biblijnego w dziedzinie modlitwy. Wręcz przeciwnie. Nawet jeśli tradycja Izraela nie była szczegółowo znana chrześcijanom pogańskiego pochodzenia, to ich świadomość, że pomiędzy Starym i Nowym Testamentem istnieje ciągłość, której gwarancją jest Duch Święty działający nieustannie w historii zbawienia, wyrażała się w przyjęciu ducha modlitwy, który przenikał oba Przymierza Boga z człowiekiem ${ }^{63}$.

czenie modlitwy w dziełach św. Łukasza, w: Studia z teologii św. Łukasza, red. F. Gryglewicz, Poznań-Warszawa-Lublin 1973, s. 138.

59 M. Simon, La civilisation de lantiquité et le christianisme, Paris 1972, s. 33-34.

${ }^{60}$ P. Łabuda, Święty Paweł trzynasty apostoł, Tarnów 2011, s. 160.

${ }^{61}$ Jak podają Dzieje Apostolskie, rodzice Pawła zapewnili mu staranne wykształcenie w Prawie ojczystym, co jest dowodem ich głębokiej religijności ( $\mathrm{Dz}$ 22, 3). Zob. P. Łabuda, Z Maryja i św. Pawłem poznawać i głosić Chrystusa, Tarnów 2009, s. 12.

${ }^{62}$ W Liście do Galatów Paweł wyjaśnia trzy prawdy, które pomagają zrozumieć tajemnicę Kościoła i tożsamość chrześcijanina: 1) przez chrzest stajemy się synami Boga, tak jak Chrystus jest Synem Ojca, dzięki temu możemy zwracać się do Boga Abba; 2) wszyscy ochrzczeni stanowią jedność z Chrystusem i 3) usprawiedliwienie dokonuje się przez wiarę i chrzest. Zob. J. Królikowski, Tajemnica Kościoła według św. Pawła, w: Benedykt xvi, Święty Paweł Apostoł Narodów, Poznań 2008, s. 108.

${ }^{63}$ Zob. B. Seremet, Dzieje Apostolskie i listy katolickie, s. 33. 


\section{Islam a chrześcijaństwo}

Zarówno chrześcijaństwo, jak i islam mają swoje korzenie na Bliskim Wschodzie. Ich rozwój i wpływy w różnych regionach, aż do światowego zasięgu, spowodowały nieuniknione spotkania i wzajemne relacje ${ }^{64}$. Informacje na temat kontaktów Muhammada z chrześcijanami, zawarte w muzułmańskich biografiach, wciąż budzą liczne kontrowersje wśród naukowców. Dotąd nie udało się ustalić zakresu tychże kontaktów. Nie ulega wątpliwości, że miały one miejsce. Wynikiem tych kontaktów jest obecność w tradycji muzułmańskiej zapożyczeń nowotestamentalnych. Nie ma jednak jasności co do genezy owych zapożyczeń ${ }^{65}$.

Podstawą modlitwy chrześcijańskiej jest Modlitwa Pańska (Mt 6, 9-13). Jej tekst, opracowany przez Abū Dāwūda, znalazł się w jednym z sześciu najbardziej cenionych zbiorów hadisów ${ }^{66}$. Spośród innych tekstów z Nowego Testamentu, których adaptacje znalazły się w muzułmańskich hadisach, na uwagę zasługuje przypowieść o robotnikach z Mt 20, 1-16 ${ }^{67}$ oraz „Roz-

${ }^{64}$ Zanim powstał islam, chrześcijaństwo było już obecne na Półwyspie Arabskim, a szczególnie na jego obrzeżach. Wraz z rozwojem chrześcijaństwa zaczęły pojawiać się wewnątrz Kościoła podziały dotyczące m.in. interpretacji nauki o pochodzeniu Ducha Świętego oraz chrystologii, które w konsekwencji doprowadziły do rozłamu pomiędzy Wschodem a Zachodem, co wywarło wpływ na kształtowanie się powstałego kilka wieków później islamu. Zob. H. Goddard, Historia stosunków chrześcijańsko-muzułmańskich, Warszawa 200o, s. 11-25.

${ }^{65}$ Zob. K. Kościelniak, Tradycja muzułmańska na tle akulturacji chrześcijańsko-islamskiej od viI do x wieku. Geneza, historia i znaczenie zapożyczeń nowotestamentowych w hadisach, Kraków 2001, s. 119.

${ }^{66}$ Dowodem na zapożyczenie tekstu z Ewangelii Mateusza jest uderzające podobieństwo hadisu AbūDāwūda do Modlitwy Pańskiej. Tekst adaptowany przez tradycję muzułmańską brzmi następująco: „Panie nasz, który jesteś w niebie, niech się święci imię Twoje, Twoja wola [niech spełnia się] na niebie i na ziemi, tak jak Twoje miłosierdzie jest w niebie, tak uczyń je na ziemi. Wybacz nam złe czyny i grzechy. Jesteś Panem dobrych ludzi, spuść część Swego miłosierdzia (łaski) i część Twego uzdrowienia na ten padół bólu, a zostanie on uzdrowiony”. Powyższy tekst można porównać także z Łk 11, 2-4: „Ojcze, niech się święci Twoje imię; niech przyjdzie Twoje królestwo! Naszego chleba powszedniego dawaj nam na każdy dzień i przebacz nam nasze grzechy, bo i my przebaczamy każdemu, kto przeciw nam zawini; i nie dopuść, byśmy ulegli pokusie". Zasadniczą różnicą muzułmańskiej modlitwy w odniesieniu do Modlitwy Pańskiej jest usunięcie określenia Ojciec, albowiem nazywanie Boga w ten sposób nie odpowiadało muzułmańskiej ideologii. Zob. K. Kościelniak, Tradycja muzułmańska..., S. 220-224.

${ }^{67}$ Pomimo wielu analogii adaptacja przypowieści posiada $\mathrm{w}$ hadisie nowy sens; bycie muzułmaninem i respektowanie prawa islamskiego jest cenniejsze od ciągłej pracy i zasługuje 
rachunek z miłości bliźniego" z Mt 25, 31-46 ${ }^{68}$. Stąd nasuwa się wniosek, iż spośród nowotestamentalnych tekstów Ewangelia Mateusza wywarła szczególny wpływ na powstawanie Koranu ${ }^{69}$.

Islam uznaje wyjątkowość Jezusa i Jego narodzenie z Dziewicy Maryi. Traktuje Go jednak wyłącznie jako proroka, odrzucając Jego Boskość i prawdę o Jego zbawczej śmierci na krzyżu. Wspólna dla islamu i chrześcijaństwa jest wiara w jednego Boga Stwórcę, sąd ostateczny oraz niebo i piekło. Islam nie wypowiada się na temat czyśćca. Ponadto nie w nim sakramentów ani odpowiednika Magisterium Kościoła ${ }^{70}$.

Zgodnie z panującym powszechnie przekonaniem, zarówno Stary Testament, jak i chrześcijaństwo stanowiły inspirację dla monoteizmu Mahometa. Monoteizm islamu jest bardzo surowy. Nie uznaje prawdy o Trójcy Świętej, Bożym ojcostwie, odkupieniu i Zbawicielu ${ }^{71}$. Allah jest Bogiem niedostępnym, kontakt z nim jest możliwy jedynie przez hołd składany podczas modlitwy. Muzułmanie uznają prawdę o zmartwychwstaniu umarłych i życiu po śmierci.

\section{Podsumowanie}

Modlitwa to jeden $\mathrm{z}$ najistotniejszych elementów kultu religijnego człowieka. O tym, jak ważne miejsce zajmuje w jego życiu religijnym, świadczy szczególna dbałość o odpowiednie przygotowanie do rozpoczęcia „rozmowy z Bogiem", zatem: określony strój, przedmioty, miejsce, czas czy rytualne oczyszczenie. Jak wynika z powyższej analizy, w poszczególnych religiach istnieją różne formy i sposoby wyrażania kontaktu człowieka z Bogiem. Jednak mają one także pewne elementy wspólne.

na podwójną nagrodę od Boga, który działa poprzez ludzi. Zob. K. Kościelniak, Tradycja muzułmańska..., s. 238.

${ }^{68}$ W adaptacji tekstu Mt 25, 31-46 tradycja muzułmańska odrzuca boski charakter Jezusa, co jest niedopuszczalne z punktu widzenia chrześcijańskiego, natomiast zrozumiałe z punktu widzenia islamu, dla którego Jezus jest jednym z proroków. Bóstwo Jezusa to najistotniejsza różnica pomiędzy chrześcijaństwem a islamem. Zob. R. Leuze, Christentumund Islam, Tübingen 1994, s. 82-83.

${ }^{69}$ Zob. J. Gnilka, Koran i chrześcijanie, s. 107.

${ }^{70}$ Zob. A. Scarabel, Islam, Kraków 2004, s. 175-176.

${ }^{71}$ Zob. K. Bukowski, Religie świata wobec chrześcijaństwa, s. 90. 
Nasza analiza ukazała pewne analogie i podobieństwa w rozumieniu modlitwy w trzech wielkich religiach świata: chrześcijaństwie, judaizmie i islamie. Te analogie: czas kształtowania się tychże religii, uwarunkowania geograficzne i kulturowe sprawiły, że ich wzajemny wpływ stał się nieunikniony. Obok istotnych różnic dotyczących form, treści i okoliczności towarzyszących modlitwie, religie te posiadają cechę wspólną, mianowicie traktują modlitwę jako formę dialogu człowieka $\mathrm{z}$ Bogiem $^{72}$. W judaizmie biblijnym modlitwa była wyrazem odpowiedzi człowieka na Boże objawienie. W islamie była obowiązkiem każdego wyznawcy.

Modlitwa w chrześcijaństwie jest formą dialogu z Bogiem, który objawił się w Jezusie Chrystusie. Dzięki wcielonemu Synowi Bożemu Bóg stał się bliski człowiekowi. Został objawiony jako Ojciec, który prowadzi dialog zbawczy z człowiekiem. Ten dialog z Ojcem dokonuje się przez Chrystusa Słowo Wcielone i w miłości Ducha Uświęciciela.

Dialog pomiędzy Bogiem a człowiekiem jest wynikiem inicjatywy Stwórcy i Jego miłości do człowieka. Odpowiedź człowieka polega na usłyszeniu słowa Bożego, przyjęciu usłyszanej prawdy i wprowadzaniu jej w życie codzienne $\mathrm{e}^{73}$.

\section{Bibliografia}

Banak J., Modlitwa w Piśmie Świętym, „Materiały Problemowe” 4 (1981), s. 72-78. Banek K., Islam, w: Słownik wiedzy o religiach, red. K. Banek, Bielsko-Biała 2007, S. $145-193$.

Bielawski J., Islam, Warszawa 1980.

Bloom M., Żydowski mistycyzm a magia, Kraków 2011.

Bukowski K., Religie świata wobec chrześcijaństwa, Kraków 1997.

Cantalamessa R., Maggioni B., Modlić się w Duchu i prawdzie. Modlitwa według Biblii, Kraków 2011.

Danecki J., Koran, w: Leksykon religioznawczy, red. W. Tyloch i in., Warszawa 1988, S. $123-124$.

${ }^{72}$ Celem tego dialogu jest zazwyczaj prośba o coś, przebłaganie za grzechy, dziękczynienie lub uwielbienie. Zob. K. Bukowski, Religie świata wobec chrześcijaństwa, s. 292-293.

73 Zob. H. Muszyński, Biblijne korzenie modlitwy, „Ateneum Kapłańskie” 75 (1983) t. 100 z. 3, s. 341-346. 
Danecki J., Podstawowe wiadomości o islamie, t. 1, Warszawa 1997.

Dziekan M. M., Jak modla się muzułmanie, Warszawa 1997.

Encyklopedia popularna PWN, red. B. Kaczorowski, Warszawa 2004.

Enzyklopädie der Religionen, Hrsg. M. Elser, S. Ewald, G. Murrer, Augsburg 1990.

Flusser D., Chrześcijaństwo religia żydowską, Warszawa 2003.

von Glasenapp H., Judaizm, w: Judaizm, red. M. Dziwisz, Kraków 1989, s. 9-38.

Gnilka J., Koran i chrześcijanie, Kielce 2010.

Goddard H., Historia stosunków chrześcijańsko-muzułmańskich, Warszawa 2000.

Jasiewicz A., Historia kształtowania się modlitwy Jezusowej, „Seminare. Poszukiwania Naukowo-Pastoralne" 25 (2008), s. 403-411.

Jóźwiak F., Znaczenie modlitwy w dziełach św. Łukasza, w: Studia z teologii św. Łukasza, red. F. Gryglewicz, Poznań-Warszawa-Lublin 1973, s. 125-140.

Kameraz-Kos N., Święta i obyczaje żydowskie, Warszawa 2006.

Kościelniak K., Tradycja muzułmańska na tle akulturacji chrześcijańsko-islamskiej od viI do x wieku. Geneza, historia i znaczenie zapożyczeń nowotestamentowych w hadisach, Kraków 2001.

Królikowski J., Tajemnica Kościoła według św. Pawła, w: Benedykt xvi, Święty Paweł Apostoł Narodów, Poznań 2008.

Leksykon podstawowych pojęć religijnych. Judaizm, chrześcijaństwo, islam, red. A. Khoura, Warszawa 1998.

Leuze R., Christentum und Islam, Tübingen 1994.

Łabuda P., Święty Paweł trzynasty apostoł, Tarnów 2011.

Łabuda P., Z Maryją i św. Pawłem poznawać i głosić Chrystusa, Tarnów 2009.

Łach J., Motywacje modlitwy w Biblii, „Studia Theologica Varsaviensia” 23 (1985)

nr 2, s. 55-71.

Mały słownik kultury świata arabskiego, red. J. Bielawski, Warszawa 1971.

Mały słownik religioznawczy, red. Z. Poniatowski, Warszawa 1969.

Martin G., Uczmy się modlić jak Chrystus, Kraków 2003.

Matea S. M., Modlitwa prośby, „Ateneum Kapłańskie” 55 (1963) t. 66, s. 338-346.

Miklicz M., Chrześcijaństwo (I tysiąclecie), w: Słownik wiedzy o religiach, red.

K. Banek, Bielsko-Biała 2007, s. 33-56.

Muszyński H., Biblijne korzenie modlitwy, „Ateneum Kapłańskie” 75 (1983) t. 100 z. 3, s. 335-348.

Pawłowicz Z., Modlitwa i mistyka islamu a chrześcijaństwo, „Ateneum Kapłańskie" 79 (1987) t. 108 z. 3, s. 407-420.

de la Potterie I., Modlitwa Jezusa, Mesjasza - Sługi Bożego - Syna Bożego, Kraków 1996. 
Quoist M., Modlitwa i czyn, Warszawa 2002.

Rahner K., Kiedy się modlisz..., Paryż 1968.

Scarabel A., Islam, Kraków 2004.

Seremet B., Dzieje Apostolskie i listy katolickie, Tarnów 2001.

Simon M., La civilisation de l'antiquité et le christianisme, Paris 1972.

Solomon N., Judaizm, Warszawa 1997.

Stachowiak L., Modlitwa w Piśmie Świętym, „Ateneum Kapłańskie” 55 (1963) t. 66 Z. 5, s. 299-309.

Szymański E., Islam pierwotny, w: Zarys dziejów religii, red. J. Keller, Warszawa 1986, s. 750-768.

Tomal M., Jak modlą się Żydzi. Antologia modlitw, Warszawa 2000.

Tyloch W., Judaizm, Warszawa 1987.

Tyloch W., Bogowie czterech stron świata, Łódź 1988.

de Vaux R., Instytucje starego Testamentu, t. 2, Poznań 2004.

de Vries S. P., Obrzędy i symbole Żydów, Kraków 1999.

Woroniecki J., Petnia modlitwy, Poznań 1982.

Yaken F., Co oznacza moja przynależność do islamu, Białystok 2000.

\section{Streszczenie}

Modlitwa jest jednym $\mathrm{z}$ najistotniejszych przejawów kultu obecnym w każdej religii. Ze względu na różnice występujące w poszczególnych religiach, a także uwarunkowania historyczne, geograficzne i kulturowe, modlitwa przybierała różnorodne formy i środki wyrazu. W niniejszym artykule zostały ukazane analogie pomiędzy modlitwą w judaizmie, chrześcijaństwie i islamie. Modlitwa Izraela wynikała $\mathrm{z}$ faktu przynależności do narodu żydowskiego, z którym Bóg zawarł przymierze. Zachowanie warunków owego przymierza stanowiło w przekonaniu człowieka wierzącego gwarancję, że jego modlitwa zostanie wysłuchana ${ }^{74}$. Właściwością modlitwy chrześcijańskiej jest jej ukierunkowanie na osobę i zbawcze dzieło Chrystusa; Jego pośrednictwo stanowi zatem gwarancję skuteczności ${ }^{75}$. Modlitwa w islamie stanowi jeden z pięciu filarów, tzn. podstawowych obowiązków, których przestrzeganie

74 Zob. L. Stachowiak, Modlitwa w Piśmie Świętym, „Ateneum Kapłańskie” 55 (1963) t. 66 Z. 5, s. 299-300.

75 J. Łach, Motywacje modlitwy w Biblii, „Studia Theologica Varsaviensia” 23 (1985) nr 2, s. $68-69$. 
jest warunkiem zbawienia. Pomimo różnic występujących w wyżej omawianych religiach ich wspólną cechą jest podejmowanie dialogu człowieka z Bogiem i przekonanie, że prośby skierowane do Niego zostaną wysłuchane.

\section{Słowa kluczowe}

modlitwa, religia, monoteizm, chrześcijaństwo, judaizm, islam

\section{Summary}

\section{Prayer's analogy and genealogy in three monotheistic religions}

Prayer is one of the most essential expression of the cult existing in every religion. On account of differences taking place in individual religions, and also historical, geografical and cultural conditionings, the prayer donned different forms and means of expression. In this article there have been featured the analogies between prayer in Judaism, Christianity and Islam. The Israel's prayer resulted from the fact of affiliation with jewish nation with which the God transacted the covenant. Perpetuating the conditions of this covenant constituted the guarantee for the believing human being that his prayer will be listened. The Christian prayer's property is it's giving direction to a person and Christ's saving work; His mediation constitutes the guarantee of effectiveness therefore. Prayer in Islam constitutes one of the five pillars, meaning elementary obligations, which abiding is the condition of the salvation. In spite of the differences taking place in above-mentioned religions their common feature is taking a dialogue between man and the God and also the belief that requests directed to Him will be listened.

\section{Keywords}

prayer, religion, monotheism, Christianity, Judaism, Islam 